2. Jonsson K. et al. Rye and health-Where do we stand and where do we go? // Trends in Food Science \& Technology. 2018. - T.79. - C. 78-87.

3. Feng G. Rye // Bioactive Factors and Processing Technology for Cereal Foods. Springer, Singapore, 2019. - P. 151-169.

4. Meija L., Krams I. Rye // Whole Grains and their Bioactives: Composition and Health. 2019. - C. 169-208.

5. Зверкова 3.Н. Использование зерна озимой ржи в кормлении крупного рогатого скота // Кормопроизводство. 2008. - № 9. - С. 24.

6. Аллабердин И.Л. Зерно озимой ржи в комбикормах для дойных коров // Достижения науки и техники АПК. 2010. - № 1. - С. 46-48.

7. Гончаренко А.А. Современное состояние производства, методы и перспективные направления селекции озимой ржи в РФ // Озимая рожь: селекция, семеноводство, технологии и производство. Уфа, 2009. - С. 40-60.

DOI 10.18699/GPB2020-99

\title{
Получение и перспективы использования дигаплоидов ячменя обыкновенного (Hordeum vulgare L.) (обзор)
}

Попова К.И., м.н.с., аспирант.

СибНИИРС - филиал ИичиГ СО РАН; НГАУ, Новосибирск, Россия.

E-mail:popova.k.i@mail.ru

Ячмень обыкновенный (Hordeum vulgare L.) является важной сельскохозяйственной культурой, которая находит применение в пивоварении, используется в кормовых и продовольственных изелях. Селекция ячменя в условиях Западной Сибири осложнена природно-климатическими особенностям. Для упрощуения и ускорения селекционного процесса, а также для решения фундаментальных генетических задач, используют дигаплоидные формы. Такие формы ячменя могут быть получены в условиях іп vivo и іп vitro. В настоящее время, в странах Европь существует большое число дигаплоидных форм ячменя обыкновенного, которые вовлекаются в селекиионные программы. Запуск подобных программ в Западной Сибири требует создание собственной базы по синтезу дигаплоидных форм ячменя.

Ключевые слова: дигаплоид, ячмень обыкновенный, Hordeum vulgare L., in vitro, культура пьльников, культура изолированных микроспор.

\section{Obtaining and prospects for the use of digaploids of barley}

(Hordeum vulgare L.) (review article)

Popova Karina Igorevna ${ }^{1,2}$

${ }^{1}$ SibRIPP\&B - branch ICG SB RAS; ${ }^{2}$ Novosibirsk State Agrarian University, 
Novosibirsk, Russia.

e-mail: popova.k.i@mail.ru

Barley (Hordeum vulgare L.) is an important crop that is used in brewing, used for feed and food purposes. Barley selection in Western Siberia is complicated by natural and climatic features. To simplify and accelerate the breeding process, as well as to solve fundamental genetic problems, dihaploid forms of barley are used. Dihaploid forms of barley can be obtained in vivo as well as in vitro. Currently, in Europe, there are a large number of dihaploid forms of barley $(H$. vulgare), which are used in breeding programs, but in Western Siberia, there is an acute shortage of such forms.

Key words: dihaploid, barley, Hordeum vulgare L., in vitro, anther culture, culture of isolated microspores.

Ячмень обыкновенный (Hordeum vulgare L.) находит широкое применение в пивоварении, используется в кормовых и продовольственных целях (получение перловой и ячневой крупы). Исследователи отмечают перспективность использования ячменя обыкновенного (H. vulgare) в качестве фиторемедиатора для очистки почв от тяжелых металлов, в частности от избыточного содержанияцинка [1]. Ячмень обыкновенный (H. vulgare) отличается бо́льшей устойчивостью к неблагоприятным факторам окружающей среды, чем пшеница и рис.

Все вышеперечисленные факты обуславливают популярность и возделывание ячменя обыкновенного во многих странах мира. По производству данной культуры в мире лидируют Россия, Канада и США [2] . Более $65 \%$ зерна идет на кормовые цели, 6-8 \% приходится на пивоварение, 15 \% ячменя идет на продовольственные нужны [2].

Ячмень обыкновенный (H. vulgare) является диплоидным $(2 \mathrm{n}=14)$ самоопылителем и имеет большой размер генома (> 5.1 гигабазы), что делает процесс секвенирования и картирования трудоемким [3].

Селекционный процесс многих культур, в том числе и ячменя, сопряжен с рядом трудностей, возникающих на фоне совокупности разнообразия природно-климатических условий и требований, предъявляемых к сорту [4]. Использование дигаплоидных форм ячменя, в качестве исходного материала, позволяет значительно ускорить селекционный процесс [5]. Данный факт обусловлен тем, что получаемые растения являются гомозиготными организмами, имеющими двойной набор одинаковых хромосом, и дальнейшее расщепление, соответственно исключено. При этом, стоит понимать, что применение дигаплоидных форм ячменя не исключает использование классических способов получения селекционного материала, а выступает в роли дополнительного метода создания новых перспективных форм. В особенно- 
сти представляют повышенный интерес гены мужской стерильности, которые у ячменя обыкновенного находятся в рецессивном состоянии, и могут быть проявлены таким методом [6]. Также, дигаплоидные формы используются и для проведения фундаментальных генетических исследований, позволяя быстро и подробно изучить не только доминантные, но и рецессивные признаки.

Впервые гаплоид ячменя был получен в 1970 году в условиях in vivo в результате межвидового скрещивания ячменя обыкновенного (H. vulgare) и ячменя луковичного (H. bulbosum) [7].

Первый гаплоид из пыльников ячменя в культуре in vitro был получен из пыльников в 1973 году [8], затем в 1976 году из семяпочки [9] и в 1991 году из изолированных микроспор [10].

В настоящий момент, гаплоиды ячменя преимущественно получают с помощью методов in vitro: культура пыльников, культура изолированных микроспор; из методов in vivo используют элиминирование хромосом $[5,6]$.

Большое число гаплоидов и дигаплоидов ячменя было получено в странах Европы и в России. В России существует два сорта ярового ячменя, которые были получены с использованием дигаплоидных форм - «Эльф»и «Тандем», данные сорта, в основном, подходят для Волго-Вятского региона [11]. В Западной Сибири, в частности в Новосибирске, сорта на основе дигаплоидных форм отсутствуют, следовательно, существует потребность в создании собственных дигаплоидных форм ячменя.

Для осуществления селекционной программы требуется большое число дигаплоидных форм. При классическом подходе, минимальная потребность составляет порядка 5000 образцов. Для реализации подобной программы требуется разработка методик высопродуктивного получения дигаплоидов ячменя собственных гибридов.

Благодарности: работа выполнена в рамках Государственного задания ИЦиГ СО РАН (проект № 0259-2019-0011).

\section{Список литературы}

1. Неведров, Н.П. Использование ячменя обыкновенного Hordeum vulgare (L.) в целях фиторемедиации / Н.П. Неведров, Е.П. Проценко, А.Е. Кузнецов // Теоретические и практические аспекты естественных и математических наук. -2012 . - № 1. C. 115-119.

2. Современные проблемы в селекции ячменя по качеству зерна / М.М. Копусь, Е.Г. Филиппов, Н.Г. Игнатьева, Н.А. Матвиевская // Известия оренбургского государственного аграрного университета. - 2004. - № 3 (3). - C. 43-46.

3. Bennett, M.D Nuclear DNA amounts in angiosperms / M.D. Bennett, J.B. Smith // Nature. - 1976. - № 491. - P. 711-716.

4. Аниськов, Н.И. Селекция ячменя в Западной Сибири / Н.И. Аниськов // Достижения науки и техники АПК. - 2009. - № 1. - С. 24-26.

5. In Vivo Haploid Production in Crop Plants: Methods and Challenges / A.Watts, V. Kumar, R. K. Raipuria, R. C. Bhattacharya // Plant Molecular Biology Reporter. - 2018. № 36. - P. 685-694. 
6. Удвоенные гаплоиды ячменя и их использование в генетико-селекционных исследованиях / Я.В. Мишуткина, Я.Б. Нескородов, М.Г. Новокрещенова и др. // Современные проблемы науки и образования. - 2013. - № 5. - С. 476-486.

7. Kasha, K.J. High frequency haploid production in barley (H. vulgare L.) / K.J. Kasha, K.N. Kao // Nature. - 1970. - Vol. 225. - P. 874-876.

8. Clapham, D. Haploid Hordeum plants from anthers in vitro / D. Clapham // Z Pflanzenzücht. - 1973. - Vol. 69. - P. 142-155.

9. San Noeum, L.H. Haploïdes Hordeum vulgare L. par culture in vitro d'ovaires non fecondés / L.H. San Noeum // Ann Amélior Plant. - 1976. - Vol. 26. - P. 751-783.

10. Culture conditions for induction of green plants from barley microspores by anther culture methods / K.N. Kao, M. Saleem, S. Abrams et al. // Plant Cell Reports. - 1991. Vol. 9. - P. 595-601.

11. ФГБУ Госсорткомиссия [Электронный ресурс]. - Режим доступа: http://reestr.gossortrf.ru/, свободный - (28.02.2020)

DOI $10.18699 / \mathrm{GPB} 2020-100$

\section{Отдаленная гибридизация как метод создания 000-форм ярового рапса (Brassica Napus L.)}

Потапов Д.А., к.с.-х.н., в.н.с.

Сибирский федеральный научный центр агробиотехнологий РАН, Новосибирск, Россия.

e-mail:d_potapov@ngs.ru

С изелью создания желтосемянного материала ярового рапса были проведены скрещчивания между видами родов Brassica u Sinapis. B качестве исходного материала использовали инбреднье линии B. пария, желтосемянныле сорта B. campestris, B. juncea u S. alba.Уcnех отдаленных скрещчиваний в значительной степени определялся родственными связями видов рода Brassica согласно схеме Nagaharu U. B результате селекционной проработки этого материала созданы формы с желтой окраской оболочки семян для выведения сортов ярового рапса в условиях Западной Сибири.

Ключевые слова: селекичя, яровой рапс, окраска оболочки семян, 000формил.

\section{Interspecific hybridization as a method for development of yellow-seeded Brassica napus $\mathrm{L}$.}

Potapov D.A., Siberian Federal Scientific Centre of Agro-BioTechnologies of the Russian Academy of Sciences; Novosibirsk, Russian Federation.

*e-mail:d_potapov@ngs.ru

Crosses between species of the genera Brassica and Sinapis were carried out to obtain a yellow-seed material of Brassica napus. Inbred lines of B. napus, 